\title{
MANAJEMEN PEMBINAAN KEDISIPLINAN SISWA: STUDI KASUS PADA ABSENSI FINGERPRINT BERBASIS SMS GATEWAY DI SMK NU KAPLONGAN INDRAMAYU
}

\author{
Ade Apriyanto \\ STKIP NU Indramayu, Jalan Raya Kaplongan No. 28 Karangampel Indramayu 45283, \\ apriyantoade190@gmail.com
}

Diterima 12 Desember 2018, disetuji 2 Februari 2019, diterbitkan 30 April 2019

Pengutipan: Apriyanto, A. (2019). Manajemen Pembinaan Kedisiplinan Siswa: Studi Kasus pada Absensi Fingerprint Berbasis SMS Gateway di SMK NU Kaplongan Indramayu. Gema Wiralodra, Vol 10, No 1, Hal 79-92, April 2019

\begin{abstract}
ABSTRAK
Tujuan penelitian adalah 1) untuk mengetahui manajemen pembinaan disiplin siswa melalui sistem absensi fingerprint berbasis SMS gateaway di SMK NU Kaplongan. 2) Untuk mengetahui efktivitas pembinaan disiplin siswa melalui sistem absensi fingerprint berbasis SMS gateaway di SMK NU Kaplongan. 3) Untuk mengetahui implikasi manajemen pembinaan disiplin siswa melalui absensi fingerprint berbasis SMS gateaway dan penegakan tata tertib terhadap peningkatan sikap disiplin siswa di SMK NU Kaplongan. Metode penelitian yang digunakan pada penelitian ini adalah metode penelitian kualitatif. Teknik pengumpulan data yang dilakukan adalah observasi berperan serta (partisipan observation), wawancara mendalam (in depth interview), dokumentasi, dan triangulasi/gabungan. Hasil penelitian ini adalah kedisiplinan siswa dapat terwujud melalui penegakan tata tertib. Proses penerapan sistem absensi fingerprint melalui beberapa tahapan, yaitu identifikasi sidik jari dan dicocokan dengan nomor induk siswa serta nomor orang tua siswa, siswa melakukan pemindaian sidik, data tersebut disalurkan kepada komputer sekolah dan diolah dengan menggunakan aplikasi khusus, setelah diolah, data tersebut dikirim ke server pusat penyedia layanan absensi fingerprint dan selanjutnya data tersebut dikirim ke berbagai pihak yang berkepentingan melalui SMS.
\end{abstract}

Kata kunci: Manajemen, disiplin, sidik jari

\begin{abstract}
ABSTRAC
The purposes of this research are to know the management of students' discipline development trough fingerprint attendance system based on SMS gateway in SMK NU Kaplongan, and to determine the effectiveness of the students' discipline development management through fingerprint attendance system based on SMS gateway SMK NU Kaplongan, and to determine the implications of the students' discipline development through fingerprint attendance based on SMS gateway about increasing students discipline in SMK NU Kaplongan. The method of research which is used is a qualitative method. The techniques of accumulation data are observation participant, in-depth interviews, documentation, and triangulation. The results of this research are firstly the discipline of student can be materialized trough applying the rules. Applying fingerprint attendance system through some steps, they are fingerprint identification and matched with student ID numbers and also their parent phone numbers. The students do it, and the data will be sent to the school computer, it will be processed and sent to the central server. Finally, the data will be sent to the head master, teachers, and their parents.
\end{abstract}

Keywords: Management, dicipline, fingerprint 


\section{PENDAHULUAN}

Sekolah sebagai organisasi di bidang pendidikan memiliki tanggung jawab dalam mengelola peserta didik agar mampu mengembangkan potensinya dirinya dan menjadi manusia yang seutuhnya, sehingga mampu membekali dirinya untuk menghadapi tantantgan kehidupan sehari-hari. Hal Senada juga dikemukakan oleh Minarti (2011) yang mengatakan bahwa disiplin yang diterapkan di sekolah adalah siswa akan belajar hidup dengan pembiasaan yang baik, positif dan bermanfaat bagi dirinya dan lingkungannya, baik saat bersekolah maupun untuk bekal hidup di kemudian hari. Pada mulanya disiplin memang dirasakan sebagai aturan yang mengekang kebebasan siswa. Akan tetapi, bila aturan tersebut dirasakan sebagai suatu yang harus dipatuhi secara sadar untuk kebaikan , lama-kelamaan akan menjadi kebiasaan yang baik.

Kedisiplinan merupakan tolak ukur yang paling utama untunk meningkatkan kepribadian siswa dalam kehidupan sehari-hari. Disiplin merupakan kunci untuk memperoleh hasil yang baik. Berdisiplin selain akan membuat seseorang memiliki tata cara bagaimana belajar yang baik juga akan menciptakan kemauan untuk hidup dan bekerja secara teratur. Disiplin pribadi akan meningkatkan ketekunan serta memperbesar kemungkinan seseorang untuk berkreasi dan berprestasi (Sukardi, 1987). Sementara itu, menurut Prijodarminto, (2014: 123) mengemukakan bahwa disiplin adalah suatu kondisi yang tercipta dan terbentuk melalui proses dari serangkaian perilaku yang menunjukkan nilai-nilai ketaatan, kepatuhan, kesetiaan, keteraturan dan atau ketertiban. Nilai-nilai tersebut telah menjadi bagian perilaku dalam kehidupannya. Perilaku itu tercipta melalui proses binaan keluarga, pendidikan dan pengalaman. Namun demikian pada umumnya, siswa pada tingkat SMA sederajat masih saja ada yang terlambat. Hal ini disebabkan oleh beberapa faktor. Faktor diri sendiri adalah faktor terbesar yang mempengaruhi keterlambatan siswa berangkat sekolah. Kebiasaan siswa yang tidur terlalu larut malam sehingga bangun kesiangan merupakan penyebab terbesar keterlambatan siswa. Penyebab terbesar kedua adalah siswa harus menempuh jarak yang agak jauh karena keterbatasan alat transportasi. Penyebab lainnya disebabkan karena kurangnya manajemen waktu siswa, misalnya ban bocor atau alasan yag lain.

Berdasarkan pemaparan di atas sekolah memiliki tanggung jawab mengelola siswa dalam penanaman sikap disiplin siswa sehingga mampu memiliki pembiasaan-pembiasaan yang positif yang akan menjadi bekal dalam menghadapi tantangan kehidupan sehari-hari. Disiplin merupakan salah satu kunci sukses dalam belajar dan kelak akan bekerja. Dengan 
memiliki pembiasaan disiplin akan terccapai tujuan-tujuan pendidikan yang diamanatkan baik secara nasioanal maupun tujuan pendidikan pada tingkat sekolah.

Sekolah sebagai lembaga pendidikan tentu berupaya menanamkan sikap disiplin melalui serangkaian manajemen pembinaan kesiswaan yang telah dibuat. Begitu pula yang sedang dijalankan oleh SMK NU Kaplongan Indramayu yang mengelola beberapa paket keahlian seperti Teknik Kendaraan Ringan (TKR), Teknik Sepeda Motor (TSM), Teknik Komputer dan Jaringan (TKJ), Administrasi Perkantoran (AP), dan Multimedia. Pada saat ini jumlah seluruh siswa sebanyak 2.200 orang (Tata Usaha SMK NU Kaplongan tahun tahun 2017-2018). Dengan jumlah siswa yang begitu banyaknya menuntut pihak sekolah untuk bekerja keras mengelola dan membina siswa agar tetanam perilaku disiplin.

Adapun upaya-upaya yang dilakukan oleh sekolah adalah memberi penjelasan tentang tata tertib sekolah pada saat masa pengenalan sekolah disertai sanksi-sanksi terhadap pelanggaran tata tertib, menambah personel dua Pembantu Kepala Sekolah bidang kesiswaan menjadi 3 orang, dan mengadakan berbagai kegiatan ektrakulikuler yang bermuatan pembinaan mental disiplin siswa seperti Latihan Dasar Kepemimpinan Siswa, kemah terpadu, dan lain-lain. Selain itu, pihak sekolah juga melibatkan para anggota IPNU dan IPPNU (nama organisasi intrasekolah yang berada dalam Lembaga Pendidikan Ma'arif NU) untuk mendisiplinkan siswa melalui penegakan tata tertib (wawncara dengan wakil kepala sekolah bidang kesiswaan).

Hal yang pokok dalam pembinaan disiplin siswa adalah masalah kehadiran siswa, mengingat jumlah siswa SMK NU Kaplongan yang begitu banyak. Sadar dengan semakin bertambahnya jumlah siswa yang sekarang sekitar 2.200 orang, pihak sekolah melakukan inovasi tata kelola pembinaan disiplin kehadiran siswa melalui kebijakan sistem absensi fingerprint berbasis SMS Gateway (diterapkan sejak tahun pelajaran 2014-2015). Sistem tersebut mencatat kehadiran baik jam masuk maupun pulang sekolah dapat terkontrol oleh berbagai pihak seperti wali kelas, orang tua, wakil kepala seklah bidang kurikulum, dan kepala sekolah. Sistem absensi fingerprint ini adalah sistem kehadiran siswa yang terintegrasi dengan sistem informaasi akademik.

Fingerprint merupakan salah datu bentuk biometric yang menggunakan karakreristik fisik penduduk untuk mengindentifikasi. Dengan adanya sistem presensi biometric fingerprint tingkat kecurangan yang sering terjadi seperti manipulasi data dan penitipan presensi dapat dikurangi (Nugroho, 2009). Dalam dunia pendidikan sistem absensi fingerprint merupakan inovasi teknologi untuk membantu sekolah dalam mengelola peserta didik untuk meningkatkan disiplin kehadiran. Dengan adanya sistem 
absensi fingerprint siswa dapat terlatih untuk disiplin. Disiplin merupakan jalan bagi siswa untuk sukses dalam belajar dan kelak ketika bekerja. Kesadaran pentingnya norma, aturan, kepatuhan dan ketaatan merupakan prasyarat kesuksesan seseorang..

Era modern yang serba digital pada saat ini berbagai cara yang dilakukan oleh sekolah untuk menanamkan sikap disiplin. Salah satu upaya tersebut adalah penerapan absensi fingerprint berbasis SMS gateway. Finger print berasal dari bahasa Inggris yang berarti sidik jari. Sidik jari adalah guratan-guratan yang terdapat di kulit ujung jari. Sidik jari berfungsi untuk member gaya gesekan lebih besar agar jari dapat memegang benda lebih erat. (Nugroho, 2009).

Absensi adalah suatu kegiatan atau rutinitas yang dilakukan oleh pegawai untuk membutikan dirinya hadir atau tidak hadir dalam bekerja di suatu instansi. Absensi Fingerprint berbasis short message service gateway merupakan alat pencatat kehadiran dengan sensor sidik jari dilengkapi dengan fitur SMS gateway. Integrasi kedua sistem tersebut enambah manfaat yang lebih banyak. Orang tua dapat mengetahui kapan putra/putrid mereka datang ke sekolah dan pulang dari sekolah dengan mudah hanya dengan via SMS dari hand phone tanpa harus bertanya ke pihak sekolah (Diartono, 2010). Penerapan sistem absensi fingerprint sesuai konsep panopticon yang digagas oleh Foucault (1975: 161). Konsep itu menjelaskan tentang relasi antara yang diawasi dan mengawasi, orang yang mengontrol dan dikontrol, orang yang merehabilitasi dan direhabilitasi, orang yang abnormal dan menormalkan dalam sebuah ruang kekuasaan.

Efek utama dari mekanisme panopticon ini adalah menimbulkan kesadaran untuk diawasi, dilihat, secara terus menerus pada diri seseorang . sebuah kesadaran yang mengisaratkan bahwa segala tindak tanduk dan gerak gerik mereka ada yang mengontrol dan mengawasi. Tentunya kesadaran diawasi dan dikontrol ini menimbulkan efek kepatuhan bahkan ketakutan (Suyono, 2002). Tidak hanya cetv, peraturan, kode etik, dan sistem absensi fingerprint di lembaga pendidikan juga bisa memerankan mekanisme panopticon.

Penelitian ini memang bukan pertama kali dilakukan, ada banyak penelitian terdahulu yang melakukan kajian yang serupa. Namun, penelitian yang dilakukan pada saat ini ada beberapa perbedaan dengan beberapa penelitian terdahulu. Berikut ini adalah beberapa penelitian yang sudah dilakukan beserta beberapa karakteristik perbedaannya: 1). Hasil penelitian ini adalah terdapat hubungan manajemen fingerprint dengan kinerja guru dan terdapat hubungan antara motivasi kerja dan kinerja guru (Mujoko, 2015). 2) Penelitian ini menghasilkan data pengukuran kinerja pegawai melalui penerapan 
mekanisme dan pencapaian target fingerprint pada pegawai negeri sipil di lingkugan sekretariat DPRD Kota Semarang (Hasiholan, L.B., \& Fathoni, A : 2016) .

Berdasarkan permasalahan di atas, penulis tertarik untuk mengkaji bagaimana manajemen pembinaan disiplin siswa melalui sistem absensi fingerprint berbasis SMS Gateway, sejauh mana efektivitas penerapan sistem absensi fingerprint terhadap peningkatan disiplin siswa di SMK NU Kaplongan Indramayu. Masalah utama dalam penelitian ini adalah sejauh mana implikasi penerapan finger print dan penegakan tata tertib terhadap perilaku disiplin siswa di SMK NU Kaplongan Indramayu.

Adapun tujuan penelitian ini adalah 1) Untuk mengetahui manajemen pembinaan disiplin siswa melalui sistem absensi fingerprint berbasis SMS gateaway di SMK NU Kaplongan. 2) Untuk mengetahui efektivitas pembinaan disiplin siswa melalui sistem absensi fingerprint berbasis SMS gateaway di SMK NU Kaplongan. 3) Untuk mengetahui implikasi manajemen pembinaan disiplin siswa melalui absensi fingerprint berbasis SMS gateaway terhadap peningkatan sikap disiplin siswa di SMK NU Kaplongan.

\section{METODE PENELITIAN}

Adapun metode penelitian yang digunakan oleh peneliti adalah metode penelitian kualitatif. Metode penelitian kualitatif adalah metode-metode untuk mengeksplorasi dan memahami makna yang oleh sejumlah individu atau sekelompok orang- dinaggap berasal dari masalah sosial atau kemanusiaan (Creswell, 2014). Sedangkan menurut Moelong (2004: 4), penelitian kualitatif adalah penelitian yang hasilnya berupa data deskriptif melalui pengumpulan fakta-fakta dari kondisi alami sebagai sumber langsung dengan instrument dari peneliti sendiri.

Penelitian ini menggunakan pendekatan studi kasus. Strategi penelitian studi kasus adalah strategi penelitian di mana didalamnya peneliti menyelidiki secara cermat suatu program, peristiwa, aktivitas, proses, atau sekelompok individu. Peneliti mengumpulkan informasi secara lengkap dengan menggunakan berbagai prosedur pengumpulan data berdasarkan waktu yang ditentukan (Creswell, 2014).

Sumber data yang digunakan penelitian ini yaitu sumber data primer dan skunder. Menurut Arikunto (2006: 129) yang dimaksud sumber data adalah subyek dari mana data dapat diperoleh. Kata-kata atau tindakan obyek yang diamati dan diwawancarai merupakan sumber data yang utama. Sumber data primer yang peneliti gunakan berupa kata-kata yang diperoleh dari sumber non formal atau interview. 
Menurut Sugiyono (2010: 308) sumber data primer adalah sumber data yang langsung memberikan data kepada pengumpul data, sedangkan sumber data sekunder merupakan sumber yang tidak langsung memberikan data, misalkan melalui orang lain atau lewat dokumen. Sumber data primer yang digunakan dalam penelitian ini adalah warga sekolah yang ada di SMK NU Kaplongan. Namun, tidak semua warga sekolah diminta untuk memberikan data. Adapun sumber data primer pada penelitian ini adalah kepala sekolah, pembantu kepala sekolah bidang kesiswaan, guru-guru atau wali kelas, anggota IPPNU/IPPNU dan orang tua siswa..

Teknik pengumpulan data merupakan langkah paling utama dalam pemelitian. Sugiyono (2010: 309) menjelaskan bahwa pengumpulan data dapat dilakukan dalam berbagai setting, berbagai sumber dan berbagai cara. Bila dilihat dari setting-nya, data dapat dikumpulkan pada setting alamiah (natural setting). Bila dilihat dari sumber datanya, dapat menggunakan sumber sumber primer dan sekunder. Bila dilihat dari segi cara atau teknik pengumpulan data dapat dilakukan dengan observasi (pengamatan), interview (wawancara), dokumentasi, dan gabungan (triangulasi).

Sugiyono (2010: 335) berpendapat bahwa analisis data adalah proses mencari dan menyusun secara sistematis data yang diperoleh dari hasil wawancara, catatan lapangan, dan dokumentasi dengan cara mengorganisasikan data, ke dalam kategori, menjabarkan ke dalam unit-unit, melakukan sintesa, menyususn ke dalam pola, memilih mana yang penting yang akan dipelajari, dan membuat kesimpulan sehingga mudah difahami oleh diri sendiri maupun orang lain.

\section{HASIL DAN PEMBAHASAN}

Istilah disiplin merupakan istilah yang sangat populer dalam kehidupan sehari-hari. Begitu pula dalam kegiatan belajar mengajar di sekolah, kata disiplin selalu disampaikan kepada para siswa supaya memiliki sikap disiplin yang baik sesuai dengan tata tertib sekolah. Disiplin cenderung diartikan sebagai hukuman dalam arti sempit, namun sebenarnya disiplin mempunyai arti yang lebih luas dan sekedar hukuman. Disiplin adalah kesanggupan menguasai diri yang diatur, disiplin berasal dari kata lain, yaitu disciplina yang artinya latihan atau pendidikan, kesopanan dan kerohanian serta pengembangan tabiat (Ali, 1998).

Adapun pengertian disiplin peserta diidk adalah suatu keadaan tertib dan teratur yang dimiliki oleh peserta didik di sekolah, tanpa ada pelanggaran-pelanggaran yang 
merugikan baik secara langsung maupun tidak langsung terhadap peserta didik sendiri dan terhadap sekolah secara keseluruhan (Imron, 2006).

Berdasarkan pengertian ini, maka disiplin peserta didik pada hakikatnya adalah kemampuan untuk mengendalikan diri dengan cara tidak melakukan sesuatu tindakan yang tidak sesuai dan bertentangan dengan sesuatu yang telah ditetapkan dan melakukan sesuatu yang mendukung dan mmelindungi sesuatu yang telah ditetapkan. Disiplin dikaitkan dengan latihan yang memperkuat, terutama ditekankan pada pikiran dan watak untuk menghasilkan kendali diri, kebiasaan untuk patuh, dan lain-lain.Disiplin dalam kaitannya dengan koreksi atau sanksi terutama diperlukan dalam suatu lembaga yang telah mempunyai tata tertib yang baik.Bagi yang melanggar tata tertib dapat dilakukan dua macam tindakan, yaitu berupa koreksi untuk memperbaiki kesalahan dan berupa sanksi.Kendali atau terciptanya ketertiban dan keteraturan. Sistem tata laku dimaksudkan bahwa setiap kelompok manusia, masyarakat, atau bangsa selalu terikat kepada berbagai peraturan yang mengatur hubungan sesama anggotanya maupun hubungannya dengan masyarakat, bangsa atau negara.

Menurut Prijodarminto (2004: 23), disiplin dapat terbentuk karena beberapa alasan berikut: (a) Disiplin akan tumbuh dan dapat dibina, melalui latihan, pendidikan, penanaman kebiasaan dan keteladanan. Pembinaan itu dimulai dari lingkungan keluarga sejak kanak-kanak. (b) Disiplin dapat ditanam mulai dari tiap-tiap individu dari unit paling kecil, organisasi atau kelompok. (c) Disiplin diproses melalui pembinaan sejak dini, sejak usia muda, dimulai dari keluarga dan pendidikan. (d) Disiplin lebih mudah ditegakkan bila muncul dari kesadaran diri. (e) Disiplin dapat dicontohkan oleh atasan kepada bawahan.

Kehadiran teknologi informasi dan komunikasi sudah memasuki ke berbagai sendi kehidupan, seperti instansi pemerintahan maupun swasta, dunia usaha, dan kehidupan sosial manusia lainnya. Selain itu, tidak luput juga masuk ke dalam dunia pendidikan. Era digitalisasi juga telah masuk kedalam dunia pendidikan khususnya sekolah. Implementasi era digitalisasi di dunia pendidikan adalah model pembelajaran yang serba on line, mengirim dan menerima data serba on line, penerimaan siswa baru juga serba on line yang semuanya tersebut memudahkan manuisa dalam menggerakkan roda pendidikan.

SMK NU Kaplongan salah satu sekolah menengah kejuruan yang berada di Kabupaten Indramayu sedang melakukan upaya penerapan teknologi informasi dan komunikasi dalam memenuhi pelayanan terhadap warga sekolah. Adapun program yang sedang diterapkan yaitu absensi fingerprint berbasis SMS Gateway. Program tersebut 
diterapkan dalam rangka menanamkan sikap disiplin siswa dalam kehadiran dengan sentuhan teknologi.

Dalam dunia pendidikan sistem absensi fingerprint merupakan inovasi teknologi untuk membantu sekolah dalam mengelola peserta didik untuk meningkatkan disiplin kehadiran. Dengan adanya sistem absensi fingerprint siswa dapat terlatih untuk disiplin. Disiplin merupakan jalan bagi siswa untuk sukses dalam belajar dan kelak ketika bekerja. Kesadaran pentingnya norma, aturan, kepatuhan dan ketaatan merupakan prasyarat kesuksesan seseorang..

Era modern yang serba digital pada saat ini berbagai cara yang dilakukan oleh sekolah untuk menanamkan sikap disiplin. Salah satu upaya tersebut adalah penerapan absensi fingerprint berbasis SMS gateway. Finger print berasal dari bahasa Inggris yang berarti sidik jari. Sidik jari adalah guratan-guratan yang terdapat di kulit ujung jari. Sidik jari berfungsi untuk member gaya gesekan lebih besar agar jari dapat memegang benda lebih erat (Nugroho, 2009).

Absensi adalah suatu kegiatan atau rutinitas yang dilakukan oleh pegawai untuk membutikan dirinya hadir atau tidak hadir dalam bekerja di suatu instansi. Absensi Fingerprint berbasis short message service gateway merupakan alat pencatat kehadiran dengan sensor sidik jari dilengkapi dengan fitur SMS gateway. Integrasi kedua sistem tersebut enambah manfaat yang lebih banyak. Orang tua dapat mengetahui kapan putra/putrid mereka datang ke sekolah dan pulang dari sekolah dengan mudah hanya dengan via SMS dari hand phone tanpa harus bertanya ke pihak sekolah (Diartono, 2010).

Proses pelaksanaan absensi fingerprint berbasis SMS Gateway di SMK NU Kaplongan meliputi beberapa tahapan, yaitu: 1)Identifikasi sidik jari setiap siswa. berdasarkan pengamatan penulis bahwa setiap siswa dipanggil setiap kelas untuk dilakukan identifikasi sidik jari dan dicocokan dengan nomor induk siswa serta nomor orang tua siswa. Operator fingerprint mengataka "Data yang diinput yaitu nomor telepon, nama siswa, NIS, dan nomor orang tua yang terpenting, karena tujuan SMS Sender adalah menginformasikan orang tua". 2) Setelah identifikasi selesai, maka siswa dapat melakukan pemindaian sidik jari dengan memasukan ibu jari ke dalam mesin absensi fingerprint. Jika penempatan sidik jari siswa dan data siswa cocok dengan identitas siswa, maka mesin fingerprint akan berbunyi "Terima Kasih", apabila siswa tersebut belum melakukan registrasi kepada operator atau penempatan sidik jari tidak benar, maka mesin fingerprint akan mengeluarkan bunyi "Silahkan Coba Lagi” (wawancara dengan Romanto, tanggal 9 Juni 2017). Mesin absensi fingerprint ditempatkan terpusat yaitu di lobi utama dekat 
kantor TU yang berjumlah 6 unit. Mesin fingerprint sengaja ditempatkan terpusat agar mudah dalam pengawasan dan perbaikan jika terjadi error atau kerusakan.

Berdasarkan pengamatan, sebelum siswa bisa melakukan pemindaian sidik jari, siswa terlebih dahulu membeli kartu perdana salah satu provider jasa telekomunikasi. Server penyedia SMS Gateway bekerja sama dengan provider jasa telekomunikasi, kemudian kartu perdana provider tersebut harus dimilki siswa seharga Rp 25.000.

Setelah para siswa melakukan pemindaian sidik jari, data tersebut disalurkan kepada komputer sekolah dan diolah dengan menggunakan aplikasi khusus yaitu SIA aplikasi yang dimiliki server pusat penyedia layanan absensi fingerprint berbasis SMS Gateway. Layanan absensi fingerprint bisa dilakukan oleh siswa SMK NU Kaplongan dibagi menjadi dua sesi, yaitu sesi pagi dan sesi siang, dikarenakan pembagian jam belajar di sekolah tersebut terbagi menjadi dua shitf. Shift pagi dilakukan oleh siswa kelas X dan Kelas XII, sedangkan shift siang dilakukan oleh siswa kelas XI.

Adapun pembatasan waktu yang diterapkan oleh SMK NU Kaplongan untuk kategori siswa hadir tepat waktu, terlambat dan tidak hadir yaitu sebagai berikut; siswa kategori tepat waktu melakukan checklock (memasukan sidik jari ke mesin fingerprint) mulai pukul 05.00 WIB sampai dengan pukul 07.15 WIB, siswa dinyatakan terlambat melakukan checklock pukul 07.15 WIB sampai pukul 08.00 WIB dan siswa dinyatakan tidak hadir melakukan checklock pukul 08.00 lebih atau tidak hadir di sekolah. Sedangkan shift siang, siswa dinyatakan hadir jika melakukan checklock mulai pukul $12.30 \mathrm{WIB}$, siswa dinyatakan terlambat jika melakukan checklock pukul 13.00-13.30 WIB, jika siswa melakukan checklock lebih dari pukul 13.30, maka dinyatakan tidak hadir.Hal demikian sesuai pernyataan yang disampaikan oleh operator absensi fingerprint SMK NU Kaplongan, berikut petikan wawancaranya:"Penentuan waktu tergantung kebijakan masing-masing sekolah, kebetulan disekolah ini membuka mesin dari jam 5 pagi sampai jam 07.15 dan dinyatakan berangkat. Namun kita melakukan estimasi bagi siswa yang terlambat sampai jam 8, berarti siswa tersebut dinyatakan terlambat, jika jam 8 lewat dinyatakan tidak hadir. Dan untuk jam siang pukul 12.30, estimasi sampai jam 13.00 sampai 13.30 dinyatakan terlambat" (wawancara dengan Romanto, tanggal 9 Juni 2017).

Setelah data diolah oleh komputer sekolah data tersebut dikirim ke server pusat penyedia layanan absensi fingerprint berbasis SMS Gateway dan selanjutnya data tersebut dikirim ke berbagai pihak yang berkepentingan seperti kepala sekolah, wakil kepala sekolah bidang kesiswaan, para wali kelas, dan orang tua siswa dalam bentuk rekapitulasi saja. 
Adapun rekapitulasi SMS Sender yang diterima oleh wali kelas sebanyak dua kali setiap hari. SMS pertama berisi jumlah siswa yang hadir dan tidak hadir, kemudian SMS kedua berisi rincian nama-nama siswa yang tidak hadir. Adapun contoh format rekapitulasi SMS sender pertama adalah sebagai berikut:"SMK NU KAPLONGAN: INFO REKAP KEHADIRAN KELAS : XI APK 2 Tgl: 13/05/2016 HADIR:25 TIDAK ABSENSI:12. KET: Perhatian, Mohon ditingkatkan prestasi Kedisiplinan kelas Anda, Terima Kasih.”

Setiap bulan hasil rekap absensi fingerprint diolah dan disampaikan kepada setiap wali kelas dalam bentuk print out. Rekap tersebut berisi daftar nama-nama kelas, wali kelas, dan presentase hadir dan tidak hadir dan rangking dari peringkat pertama hingga akhir. Hasil rekap kehadiran baik berupa SMS yang diterima oleh wali kelas setiap hari maupun rekapitulasi setiap bulan harus ditindaklanjuti oleh pihak-pihak terkait. Tindak lanjut tersebut berupa pembinaan, pemberian sanksi dan lain sebagainya.

Selain itu, orang tua siswa pun dapat menerima laporan kahadiran putra-putrinya melalui SMS Sender yang diterima setiap harinya. SMS yang diterima orang tua siswa berupa informasi kehadiran anak-anaknya dapat dijadikan bahan monitoring dan pembinaan yang dilakukan orang tua siswa. Sehingga, pihak sekolah dan orang tua siswa sama-sama mengontrol, mengawasi dan membina peserta didik.

Suatu program atau sistem terdapat kelemahan/kendala dan keunggulan. Begitupula dalam penerapan sistem absensi fingerprint berbasis SMS gateway di SMK NU Kaplongan. Berikut ini adalah kendala/hambatan yang dihadapi: 1) Siswa tidak memberikan data yang valid seperti memalsukan nomor telepon orang tua mereka beralasa jika nomor orang tua diinput maka mereka takut terpantau oleh orang tua, kartu perdana seluler yang sudah dibeli dan dibagikan tidak digunakan oleh siswa dengan alasan hanya memiliki satu hand phone, dan ada orang tua siswa yang tidak bisa mengoperasikan alat komunikasi. 2) fingerprint adalah penempatan mesin fingerprint yang tersebar dibeberapa titik sehingga rentan dibuat maianan oleh siswa yang jahil, mesin fingerprint sangat sensitif penggunaannya pun harus hati-hati, sehingga pihak sekolah menempatkan mesin fingerprint pada satu titik yaitu lobi depan guna mempermudah pengawasan mesin fingerprint oleh guru-guru maupun oleh operator fingerprint. 3) kesadaran siswa untuk melakukan checklock (memasukan ibu jari siswa ke dalam mesin fingerprint). Sedangkan sistem ini mengharuskan siswa untuk melakukan checklock, jika siswa datang ke sekolah, namun tidak melakukan checklock maka siswa tersebut dinyatakan terlambat melakukan checklock pukul 07.15 WIB sampai pukul 08.00 WIB dan siswa dinyatakan tidak hadir melakukan checklock pukul 08.00 lebih atau tidak hadir di sekolah dalam pelaporan SMS 
Sender yang diterima oleh pihak-pihak terkait. 4) rekap kehadiran dalam waktu satu bulan atau SMS sender setiap hari sering terlambat tidak rutin disampaiakan. 5) segi efektivitas dan keakurasian data yang diterima melalui SMS Sender masih belum akurat, seperti yang diungkap oleh wali kelas X TSM 2 melalui wawancara, berikut petikan wawancaranya "Menurut saya sebenarnya cukup membantu, akan tetapi selama ini belum ada pengaruh yang berarti, karena faktor kesalahan atau ketidaksesuaian data fingerprint. Tentu efektif menggunakan fingerprint namun hanya dari segi system, informasi jadi lebih cepat."(wawancara dengan Bpk Tobiin, tgl 10 Juni 2017). 6) membutuhkan anggaran yang besar dalam penerapan sistem tersebut, karena menggandeng pihak luar. 7) masih banyak orang tua siswa yang belum pernah menerima laporan dari SMS sender. Hal demikian sesuai dengan hasil wawancara dengan wali kelas XI TSM 4 (wawancara tanggal 11 Juni 2017) yang menurut penulis selalu intensif menangani siswa yang melanggar tata tertib sekolah salah satunya sering memanggil orang tua siswa. Ketika ditanya tentang apakah menurut pengakuan orang tua setiap hari mendapatkan SMS Sender, beliau menjawab demikian:"Tidak, karena masih banyak orang tua yang belum mendapat semua informasi tentang anaknya disekolah, hal ini merupakan masukan yang sangat penting menurut saya mengingat belum pernah ada diadakannya pertemuan wali murid secara resmi, baru rencana."

Selain kendala-kendala yang dihadapi, penerapan sistem ini memiliki keunggulankeunggulan, seperti:1) Membantu pihak-pihak terkait dalam memperoleh informasi kehadiran siswa secara cepat dan terpadu. 2) Sebagai bahan monitoring dan evaluasi bagi wali kelas dalam melakukan pembinaan kedisiplinan siswanya. 3) Sebagai bahan monitoring dan evaluasi bagi kepala sekolah dalam melakukan pembinaan bagi para wali kelas.

Pemanfaatan perkembangan IT yang begitu pesat diimplementasikan dalam upaya digitalisasi kehadiran siswa melalui sistem absensi fingerprint berbasis SMS Gateway. Penerapan kebijakan sistem absensi fingerprint berbasis SMS otomatis yang dilakukan oleh sebuah lembaga pendidikan memang sangat membantu dalam pengawasan dan evaluasi yang berkaitan dengan kehadiran siswa. Karena dengan teknologi inilah salah pekerjaan guru dapat dibantu dengan mudah dan cepat. Informasi yang cepat tentang kehadiran siswa bertujuan untuk meningkatkan pelayanan terhadap siswa yang membutuhkan perhatian khusus masalah kehadiran, sehingga siswa tersebut memiliki sikap disiplin waktu dan disiplin belajar yang baik. 
Penerapan kebijakan sistem absensi fingerprint di SMK NU Kaplongan mendapat respon yang baik dari para steakholder seperti para siswa-siswi, guru, orang tua siswa. Berdasarkan pemaparan tentang implementasi absensi finger print berbasis SMS gateway dan berbagai kendala yang dihadapi, dapat disimpulkan bahwa upaya sekolah dalam menanankan sikap disiplin melalui sistem absensi fingerprint berbasis SMS Gateway belum menghasilkan implikasi perubahan sikap disiplin kehadiran siswa yang signifikan. Sistem ini hanya baru mengambil dua sisi manfaat yaitu penyebaran, penerimaan informasi kehadiran siswa dan informasi lainnya kepada seluruh stakeholder dengan cepat, up to date, dan real time. Manfaat yang kedua adalah terjalin komunikasi yang baik antara sekolah dan orang tua siswa. Hal demikian diperkuat dengan pernyataan dari beberapa guru atau wali kelas mengenai efektifitas penerapan sistem absensi fingerprint berbasis SMS Gateway.

Selain menerapkan sistem absensi fingerprint berbasis SMS Gateway SMK NU Kaplongan juga melakukan upaya penegakkan tata tertib sekolah dalam upaya menananamkan sikap disiplin. Berdasarkan pengamatan dan analisis yang dilakukan oleh peneliti, penegakkan tata tertib di SMK NU Kaplongan dilakukkan oleh berbagai pihak seperti Kepala Sekolah, Para Pembantu Kepala Sekolah Bidang Kesiswaan, Para Wali kelas atau guru, dan Anggota IPNU dan IPPNU. Masing-masing pihak melaksanakan kegiatan penegakkan tata tertib sekolah sesuai dengan tupoksinya masing-masing dalam rangka menanamkan perilaku disiplin.

Kepala sekolah melakukan upaya menanamkan disiplin siswa melalui penyampaian motivasi dan semangat dalam belajar serta menanamkan makna penting dari sikap disiplin dalam berbagai kesempatan seperti kegiatan OSPEK, Pesantren Intensif Ramadhan, Ketika menjadi Pembina Upacara bendera, Peringatan Hari Besar Nasional, dan lain-lain. Kepala sekolah juga memonitoring dan mengevaluasi kehadiran siswa melalui laporan rekapitulasi kehadiran setiap kelas yang diperoleh dari wali kelas setiap bulan, serta mengevalusinya pada saat rapat dewan guru.

PKS Bidang Kesiswaan melakukan upaya penanaman sikap disiplin melalui penegakkan tata tertib siswa, melakukan serangkaian kegiatan pembinaan kesiswaan seperti LDKS (Latihan Dasar Kepemimpinan Siswa), Kemah Terpadu. Selain itu, PKS bidang kesiswaan melakukan monitoring kehadiran siswa dengan merekapitulasi kehadiran setiap bulan, kemudian menilai rekap kehadiran tersebut. Siswa yang memiliki masalah kehadiran selanjutnya diberi pembinaan dan arahan. 
Guru atau wali kelas merupakan garda terdepan dalam mendidik dan membina siswa. Wali kelas melakukan tindakan terhadap siswa yang memiliki masalah kehadiran. Tindakan tersebut dilakukan dengan tiga tahap SP 1 (Surat321P 2 disertasi surat perjanjian tidak akan mengulangi lagi, dan SP 3 (tahap pengunduran diri). Selain itu, guru juga membina hal-hal lain yang berkaitan dengan masalah siswa. Anggota IPNU dan IPPNU melakukan upaya penegakkan beberapa tata tertib siswa seperti menindak siswa yang terlambat datang pada pukul 07.10 WIB, menindak sepatu berwarna selain hitam, menindak kerapihan dan kelengkapan atribut, dan lain sebagainya. Tindakan IPNU dan IPPNU tersebut tentunya dibawah kordinasi dan instruksi PKS bidang kesiswaan.

Upaya penegakkan tata tertib siswa yang dilakukan SMK NU Kaplongan dengan cara nasehat-nasehat yang baik. Selain itu, sekolah juga tidak segan memberikan sanksi (punishment) terhadap siswa yang melanggar tata tertib. Pemberian sanksi dalam dunia pendidikan adalah suatu tindakan yang wajar dan sah-sah saja, bahkan dalam UU Sisdiknas pun sudah mengatur. Pemberian sanksi atau hukuman pun tidak berupa fisik yang dapat menciderai anak, karena sanksi atau hukuman demikian dapat merusak secara mental dan psikis anak.

Berdasarkan pemaparan di atas dapat disimpulkan bahwa upaya penanaman sikap disiplin yang dilakukan oleh Kepala Sekolah, Para Pembantu Kepala Sekolah Bidang Kesiswaan, Para Wali kelas atau guru, dan Anggota IPNU dan IPPNU sudah cukup memberikan implikasi terhadap peningkatan kedisiplinan siswa, meskipun belum optimal. Hal demikian terlihat dari upaya sebagian besar wali kelas dan PKS bidang kesiswaan yang terus memonitor dan mengevaluasi kehadiran siswa-siswi baik per minggu maupun perbulan. Selain itu, pelibatan peran anggota IPNU dan IPPNU dalam menegakkan tata tertib di beberapa sektor sudah sangat membantu dalam peningkatan disiplin siswa.

\section{KESIMPULAN}

Kesimpulan dari penelitian ini adalah kedisiplinan siswa dapat terwujud melalui penegakan tata tertib siswa yang dilakukan oleh kepala sekolah, PKS bidang kesiswaan, wali kelas, guru, anggota IPNU dan IPPNU. Sedangkan kebijakan penerapan sistem absensi fingerprint berbasis SMS gateway belum berimplikasi positif terhadap kedisiplinan siswa. Adapun faktor-faktor yang menyebabkan penerapan sistem absensi fingerprint belum memberikan implikasi positif terhadap kedisiplinan siswa adalah sebagai berikut: 1) Informasi kehadiran melalui SMS yang diterima oleh berbagai pihak, khususnya para guru/wali kelas belum secara optimal ditindaklanjuti dengan baik, sehingga upaya 
penanaman sikap disiplin, terutama disiplin kehadiran kurang berjalan dengan baik.

2)Akurasi informasi kehadiran siswa belum akurat. Hal tersebut dikarenakan banyak siswa yang memalsukan nomor orang tua, banyak siswa yang mengaku sudah checklock (memasukkan sidik jari ke dalam mesin fingerprint) namun laporan SMS Sender dinyatakan tidak hadir

\section{DAFTAR PUSTAKA}

Ali, M. (1998). Kamus Lengkap Bahasa Indonesia Modern. Jakarta: Pustaka Amani.

Arikunto, S. (2006). Prosedur Penelitian Suatu Pendekatan Praktik. Edisi revisi VI. Jakarta:Rineka Cipta.

Creswell, W. J. (2014). Research Design (Pendekatan Kualitatif, Kuantitatif, dan Mixed) Cetakan IV (Terjemahan Achmad Fawaid ). Yogyakarta:Pustaka Pelajar.

Creswell, W. J., 2014. Penelitian Kualitatif dan Desain Riset (Memilih diantara Lima Pendekatan), ( Terjemahan Achmad Fawaid ) Yogyakarta:Pustaka Pelajar.

Diartono, D. A. (2010). Integrasi Sistem Presensi Fingerprint dan Sistem SMS Gateway untuk Monitoring Kehadiran Siswa. Jurnal Teknologi Informasi DINAMIK, Vol 14, No. 1

Foucault, M. (1975). Surveiller et Punir. Paris:Gallimard.

Rosidi, R. I. (2004). Membuat Sendiri SMS Gateaway (ESME) Berbasis Protokol SMPP. Yogyakarta: Andi Offset.

Hasiholan, L.B., \& Fathoni, A. (2016). Pengaruh Mekanisme Fingerprint, Prosedur Fingerprint, Pencapaian Target Fingerprint Terhadap Kedisiplinan Pegawai di Sekretariat DPRD Kota Semarang. Journal of Manajemen, Vol 2, No 2.

Suyono, S. J. (2002). Tubuh Yang Rasis, Yogyakarta: Pustaka Pelajar.

Minarti, S. (2011). Manajemen Sekolah (Mengelola Lembaga Pendidikan Secara Mandiri). Ar-ruz Media: Jogjakarta.

Nugroho, E. (2009). Biometrika, mengenal sistem identifikasi masa depan. Yogyakarta: Andi Offset.

Prijodarminto, Soegeng. 2004. Disiplin Kiat Menuju Sukses. Jakarta: Abadi.

Sugiyono. 2010. Metode Penelitian Pendidikan (Pendekatan Kuantitatif, Kualitatif, dan $R$ dan D). Cetakan ke- 11. Bandung: Alfabeta. 